\title{
NEW AUSTRALIAN TAXA IN JUNCUS (JUNCACEAE)
}

\author{
by L.A.S. Johnson
}

(with one table and ten text-figures)

\begin{abstract}
From southeastern Australia, including Tasmania, the Juncus alexandri complex (in section Genuini) is discussed, with new taxa: J. alexandri L. Johnson subsp. alexandri and subsp. melanobasis L. Johnson, J. laeviusculus L. Johnson subsp. laeviusculus and subsp. illawarrensis L. Johnson, J. bassianus L. Johson, J. astreptus L. Johnson. Three new species of section Septati are also described from the same region: J. ratkowskyanus L. Johnson, J. curtisiae L. Johnson, J. thompsonianus L. Johnson; all are small mat-forming plants.
\end{abstract}

Key words: Juncaceae, Juncus, Australia, Tasmania.

In BANKS, M.R. et al. (Eds), 1991 (31:iii): ASPECTS OF TASMANIAN BOTANY - A TRIBUTE TO WINIFRED CURTIS. Roy. Soc. Tasm. Hobart: 35-46. https://doi.org/10.26749/rstpp.124.2.35

\section{INTRODUCTION}

So that they can be treated in the monocot volume of The Students' Flora of Tasmania, several taxa of Juncus need description. These have been studied as part of the continuing revision of Juncus in Australia and neighbouring regions, and their relationships will be treated more fully in due course.

Here it is convenient to describe also some further species very closely related to Tasmanian species.

\section{THE JUNCUS ALEXANDRI COMPLEX}

The first group may be called the Juncus alexandri complex. These are members of section Genuini, which is exceptionally well developed in the Australian region, with about 35 species. The author has previously referred to most of the alexandri complex as $J$. "sp. $\mathrm{D}_{1}$ " (e.g. in Jacobs \& Pickard 1981), so designated because of similarity and earlier confusion with $\boldsymbol{J}$. continuus L. Johnson, which was formerly tagged as $J$. "sp. D". Another somewhat similar but quite distinct species from New South Wales and southern Queensland, J. "sp. $\mathrm{D}_{2}$ ", is yet to be described.

Closer investigation showed that "sp. D,", for which the manuscript epithet "melanobasis" had been used, was not a simpleentity, either on the Australian mainland or in Tasmania, and that another undescribed Tasmanian taxon (described below as $J$. astreptus) was also intimately associated with the group.

Six taxa are now distinguished, comprising four species and two additional geographic subspecies within the mainland species. Two of the species are partly sympatric in Tasmania, and two similarly overlap in other parts of Australia.
The general range of the characters is set out in table l, but it should be borne in mind that Juncus plants often occur in a depauperate condition, and that vegetative organs and inflorescence size can be reduced in such cases. Comparisons and collections should be made of well-grown plants.

Capsule length is measured axially whereas tepal length is taken along the full curve of the tepals, and whether the capsules equal or exceed the outer tepals is thus not simply a matter of relative length measurements. Moreover, old, opened capsules collapse inwards at the top, so that relative length refers to the condition in ripe but unopened capsules.

Culm anatomy is highly significant in section Genuini and, despite great familiarity with the group, I frequently cut culm sections to be sure of identity, especially of incomplete, immature or overmature specimens. This is quite a simple matter: it needs only a quick handsection using a sharp razor blade and cutting at a third to halfway from the culm base. If fresh material is not available, a short culm segment may be soaked briefly in detergent solution at least at one cut end. The elaborate procedures of professional plant anatomists, involving dehydration, staining, embedding and microtoming, are quite superfluous in checking the features of Juncus anatomy used for quick or extensive taxonomic comparison. In my experience, the same applies in many plant groups. However, examination by low- and sometimes medium-power of a compound microscope is necessary.

A general feature of the $J$. alexandri group (shared with Juncus continuus L. Johnson, J. procerus E. Mey., I. gregiflorus L. Johnson and a number of other species) is the combination of superficial (i.e. not sunken) stomates and sclerenchyma girders (forming the culm striations) that are narrow, more-or-less parallel-sided and deep as seen in transverse section. The stellate pith 
TABLE 1

Characters of the Juncus alexandri Complex

Measurements exclude those of very depauperate plants. Culm diameter and anatomical characters are taken at one-third to one-half of height of culm. Culm height excludes length of primary bract. Cataphyll bases may be blackish (not red-black) in any of the taxa if long submerged in water, colour here refers to non-submerged cataphylls. Small sclerenchyma patches, if present, do not extend radially inwards to vascular strands.

\begin{tabular}{|c|c|c|c|c|c|c|}
\hline \multirow[t]{2}{*}{ Character } & \multicolumn{2}{|c|}{ J. alexandri } & \multicolumn{2}{|c|}{ J. laeviusculus } & \multirow[t]{2}{*}{$J$. bassianus } & \multirow[t]{2}{*}{$J$. astreptus } \\
\hline & ssp. alexandri & ssp. melanobasis & ssp. laeviusculus & ssp. illawarrensis & & \\
\hline \multicolumn{7}{|l|}{ culm } \\
\hline - height (m) & $0.7-1.25$ & $0.7-1.50$ & \multicolumn{2}{|c|}{$0.7-1.25$} & $0.6-1.00$ & $0.6-1.00$ \\
\hline - diameter (mm) & $2.0-3.5$ & $2.0-4.0$ & $2.0-3.5$ & $2.0-3.5$ & $(0.6) 1.0-3.5$ & $1.5-4.0$ \\
\hline striations & \multirow{2}{*}{\multicolumn{2}{|c|}{$40-60$}} & \multirow{2}{*}{\multicolumn{2}{|c|}{$\begin{array}{l}40-60 \\
\text { weak }\end{array}$}} & & \\
\hline $\begin{array}{l}\text { - number } \\
\text { - prominence }\end{array}$ & & medium-strong & & & $\begin{array}{l}30-50 \\
\text { weak }\end{array}$ & $\begin{array}{l}30-50 \\
\text { medium }\end{array}$ \\
\hline anatomy & & & & & \\
\hline $\begin{array}{l}\text { - epidermal cells } \\
\text { (radial elongation) }\end{array}$ & + & $\pm *$ & \multicolumn{2}{|c|}{-} & - & - \\
\hline - small scler. patches & \multicolumn{2}{|c|}{- or few } & \multicolumn{2}{|c|}{ - or few } & - or few & $(-$ or $)$ few \\
\hline $\begin{array}{l}\text { - "cortical" airspaces } \\
\text { - pith (continuous or } \\
\text { interrupted) }\end{array}$ & \multicolumn{2}{|c|}{ continuous } & $\begin{aligned} &+ \\
& \pm \text { int. }\end{aligned}$ & $\begin{array}{c}\text { - or few } \\
\pm \text { int. or cont. }\end{array}$ & $\begin{array}{l}- \text { to }+ \\
\text { cont. }\end{array}$ & $\begin{array}{l}- \text { to }+ \\
\pm \text { int. }\end{array}$ \\
\hline \multicolumn{7}{|l|}{ longest cataphyll } \\
\hline - length $(\mathrm{m})$ & \multirow{2}{*}{\multicolumn{2}{|c|}{$\begin{array}{c}(1.0) 1.2-2.5 \\
0.7-1.5\end{array}$}} & \multicolumn{2}{|c|}{$0.5-2.0$} & $0.5-1.5$ & $0.45-1.2(-1.5)$ \\
\hline - breadth (mm) & & & \multirow{2}{*}{\multicolumn{2}{|c|}{$\begin{array}{c}0.7-1.7 \\
\text { (dark)(red-)brown }\end{array}$}} & $0.5-1.3$ & $0.7-1.3$ \\
\hline - base colour & (red-) brown & red-black & & & red-brown & brown \\
\hline primary bract (m) & $0.3-1.0$ & $0.4-1.8$ & \multicolumn{2}{|c|}{$0.3-1.2$} & $0.2-1.0(-1.3)$ & $0.25-0.9$ \\
\hline inflorescence & \multirow{3}{*}{\multicolumn{2}{|c|}{$\begin{array}{l}\text { diffuse } \\
(0.2-) 0.3-1.1\end{array}$}} & \multirow{2}{*}{\multicolumn{2}{|c|}{ diffuse }} & & \multirow{3}{*}{ clustered } \\
\hline- form & & & & & diff. (-clust.) & \\
\hline $\begin{array}{l}\text { - length above } \\
\text { origin }(m)\end{array}$ & & & $0.3-1.0$ & $<0.1-0.4(-0.9)$ & $<0.1-0.3$ & \\
\hline outer tepals (mm) & $1.5-2.2(-2.6)$ & $(2.0-) 2.2-2.9$ & \multicolumn{2}{|c|}{$1.4-2.1$} & (1.9-) $2.4-3.0$ & $1.8-2.5$ \\
\hline capsules & \multirow{2}{*}{\multicolumn{2}{|c|}{$2.0-2.2$}} & \multirow{3}{*}{\multicolumn{2}{|c|}{$\begin{array}{c}2.0-2.2 \\
\pm\end{array}$}} & & \\
\hline - length $(\mathrm{mm})$ & & & & & $2.4-2.6$ & $2.0-2.5$ \\
\hline - exceeding tepals & \pm to + & \pm & & & + & \pm \\
\hline
\end{tabular}

* $\pm=$ approximately equal 
cells are generally smaller than those in J. continuus, giving the pith a whiter appearance.

The term cataphyll is used for the almost bladeless leaf-sheaths characteristic of section Genuini. The primary bract is the large erect, terete bract that has the appearance of a continuation of the culm.

\section{Juncus alexandri L. Johnson, sp. nov.}

Herba perennis, rhizomate horizontali. Cataphylla laxe voluta, basi extus castanea vel atra, intus aurea vel cuprea, cataphyllum longissimum (100)-120-250 mm longum, 7-14 $\mathrm{mm}$ latum. Culmi erecti, rigides, virides non glauci, $0.5-1.5 \mathrm{~m}$ alti, $2-4 \mathrm{~mm}$ diametro; 40-60 striis instructi; cellulis epidermalibus striarum plusminusve radialiter elongatis, medulla continua; stomatibus superficialibus. Bractea primaria culmiformis, 30-180 mm longa; bractea secundaria 4-10 mm longa. Inflorescentia diffusa, $20-110 \mathrm{~mm}$ longa, nonnullis ramis saepe plusminusve recurvatis. Tepala straminea, externa $1.5-2.9 \mathrm{~mm}$ longa. Stamina 3 (rare 4-?5); antheris circa $0.5 \mathrm{~mm}$ longis. Capsula tepala aequans vel aliquanto excedens, aureobrunnea, 2.0-2.2 mm longa.

\section{Holotype}

Cumberland Falls road turnoff from Lake Mountain road, east of Marysville on Main Divide, c. $3000 \mathrm{ft}$ alt. [c. $900 \mathrm{~m}$ ], Victoria, A.T. Johnson \& L. A. S. Johnson 7672a, 24.iv.1973, on roadside in moist area in forest of Eucalyptus nitens and E. delegatensis (NSW). Isotype: MEL.

\section{Description}

Perennial with horizontal rhizome. Cataphylls lax, reddish to chestnut-brown to black at the base outside, golden to copper-coloured inside; longest cataphyll (100-)120-250 mm long, 7-14 mm broad. Culms erect, rigid, green not glaucous, $0.5-1.5 \mathrm{~m}$ tall, $2-4 \mathrm{~mm}$ diam., striations $40-60$ with the epidermal cells of the striae more or less radially elongated; pith continuous; stomates superficial. Primary bract culmiform, 30-180 mm long, second bract 4-12 mm long. Inflorescence diffuse, $20-110 \mathrm{~mm}$ long, often with some branches somewhat reflexed. Tepals stramineous, the outer $1.5-2.9 \mathrm{~mm}$ long. Stamens 3 (rarely 4-5?), anthers c. $0.5 \mathrm{~mm}$ long. Capsule equalling or somewhat exceeding the tepals, golden brown, $2.0-2.2 \mathrm{~mm}$ long.

The epithet refers to one of the collectors of the holotype, my son Alexander Timothy Johnson. The orthography alexandri is in accordance with Recommendation 73C.2 of the International Code of Botanical Nomenclature (1988), is deliberate and is not to be altered.
The species comprises two geographic races recognised as subspecies and distinguished as follows (see also table 1):

1. Cataphylls chestnut or reddish brown (not blackish) toward the base; "cortical" air-spaces of the culms absent or few or small; tepals short to medium, 1.5-2.2(-2.6) $\mathrm{mm}$ long ............ subsp. alexandri

1*. Cataphylls becoming very dark (reddish black to black) toward the base; "cortical" air-spaces well developed; tepals medium to long, (2.0-)2.2$2.9 \mathrm{~mm}$ long................... subsp. melanobasis

\section{J. alexandri subsp. alexandri}

The distinctive characters are as in the key above.

\section{Distribution}

From the Southern Tablelands of New South Wales (including ACT) through the highlands of eastern Victoria to northeast of Melbourne, in moist cool forest country, not on very nutrient-poor soils (fig. 1).

\section{Selected Specimens}

New South Wales: Southern Tablelands - New Chum Road, Cotter Valley (ACT), N. Burbidge 7424, 30.iii.1964 (CANB, NSW); Bunberry Creek on the Wadbilliga fire trail, $39 \mathrm{~km}$ ESE of Cooma, R. Coveny 6600, P. Hind \& M. Parris , 3.viii.1975 (NSW).

Victoria: East Gippsland - Bonang Hwy, north of Mt Tingaringy turn-off, A. Beauglehole 35659, 31.xii.1970; Tambo River, c. 17 miles [27 km] east of

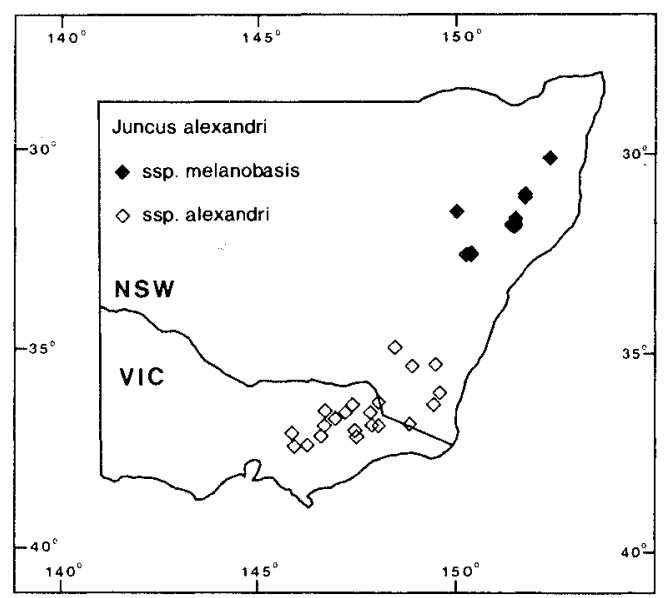

FIG. 1-Distribution of J. alexandri: two subspecies. 
Omeo, A. Beauglehole 41550, 18.ii.1973 (NSW, MEL). Victorian Flighlands - Big Hill Lookout, c. 4 miles [7 km] SSE of Mt Beauty, A. Rodd 396, 30.xii.1966 (NSW); Annie River, south of junction with Buckland River, c. 17 miles [27 km] south of Bright, A. Beauglehole 43642, 27.xi.1973 (NSW, MEL). Snowfields - Caledonia Swamp, upper reaches of East Caledonia River. c. 13 miles $[21 \mathrm{~km}] \mathrm{NNW}$ of Mt Wellington, A. Beauglehole 40997 \& E. Beauglehole, 6.i.1973 (NSW, MEL); between the Link Rd turnoff and Matlock at c. $1000 \mathrm{~m}$, L. Johnson NSW95592, 22.1.1967 (NSW); Lake Mountain, M. Tindale 770, 8.iv.1973 (NSW, MEL).

Specimens from the southwestern end of the range appear to have the smallest flowers, in general. The distributiongap between the subspecies may be smaller than shown in figure 1 , but probably does exist in the drier country around $35^{\circ} \mathrm{S}$.

\section{Hybrid}

One specimen (see fig. 3) by its characters strongly suggests hybridity between $J$, alexandri subsp. alexandri and $J$. laeviusculus subsp. laeviusculus, although we have as yet no specimens of the latter taken from this area. This is:

New South Wales: Southern Tablelands Yarrangobilly Caves to Snowy Mountains Hwy (western access), L. Johnson NSW68936, 30. iii.1964 (NSW).

In considering this occurrence, one needs to bear in mind the potential mobility of these taxa, and the effect of disturbance of the habitat.

\section{J. alexandri subsp. melanobasis L. Johnson, subsp. nov.}

A subspecie typica differt: cataphylla versus basin rubroatra vel atra; lacunae aeruginosae culmorum praesentes; tepala externa $(2.0-) 2.2-2.9 \mathrm{~mm}$ longa.

\section{Holotype}

Warung State Forest, near Norfolk Falls, western end of Liverpool Range northeast of Coolah, N.S.W., L.A.S. Johnson NSW 96382, 25.x.1966, ... in small creek ... Forest of Eucalyptus dalrympleana and E. pauciflora on basalt (NSW). Isotypes: CANB, MEL.

\section{Description}

This subspecies is distinguished by the characters given in the key above. The epidermal cells over the striations formed by the sclerenchymatous "girders" of the culms are not so pronouncedly enlarged as is usual in subsp. alexandri.

\section{Distribution}

Cool wet parts of the higher North Coast ranges, Northern Tablelands and Central Tablelands of New South Wales, in wet places, often disturbed, in forest country on soils of moderate to high fertility (fig. 1).

\section{Selected Specimens}

New South Wales: North Coast - $1 \mathrm{~km}$ south of Mt Paterson, J. Pickard 2317, 19.v.1973 (NSW); Upper Allyn, L. Johnson NSW 105128, 30.v.1970 (NSW). Northern Tablelands - c. $6 \mathrm{~km}$ west of Ebor on Guyra Rd, K. Wilson 6168, 4.v.1985 (NSW, CHR, UNE); about halfway from Tia to Nowendoc, L. Johnson 8335, $30 . i .1977$ (NSW); $3 \mathrm{~km}$ northeast of Polblue Swamp, Barrington Tops area, B. Briggs 3182 \& L. Johnson, 11.iii.1970 (NSW). Central Tablelands - Mt Coricudgy to Kerry Mountains, C. Ingram NSW 25228, ix.1953 (NSW); below Mt Coricudgy summit, $46 \mathrm{~km}$ by road ESE of Rylstone, R. Coveny 6626 \& P. Hind, 10.viii.1975 (NSW).

The epithet is from the Greek melanos "black" and basis "bottom", referring to the colour of the cataphylls.

Specimens will be found determined earlier by me using melanobasis as a specific epithet. These may belong to various of the other taxa dealt with here and should be redetermined according to their characters and localities.

\section{Hybrids}

In the area of sympatry there is evident hybridism between $J$. alexandri subsp. melanobasis and $J$ laeviusculus subsp. laeviusculus. The distribution of these apparent hybrids is shown in figure 3.

Selected Specimens ( $J$. alexandri subsp. melanobasis $\times J$. laeviusculus subsp. laeviusculus): New South Wales: Northern Tablelands - Gibraltar Range on new highway, M. Gray 3211, 1.iv.1955 (NSW); Gloucester Tops, O. Evans \& I. Burgess NSW 65375, 22.v.1962 (NSW).

Occasional hybrids occur with $J$. continuus (which grows on more sandy soils). These have somewhat paler cataphylls, longer and straighter inflorescences and rather larger pith cells.

\section{Juncus laeviusculus L. Johnson, sp. nov.}

$J$. alexandri affinis sed characteribus sequentibus differt: culmi leviter striati, cellulis epidermalibus striarum radialiter non vel vix elongatis; medulla frequenter interrupta rariore continua; tepala brevia (externa $1.4-2.1 \mathrm{~mm}$ longa). 


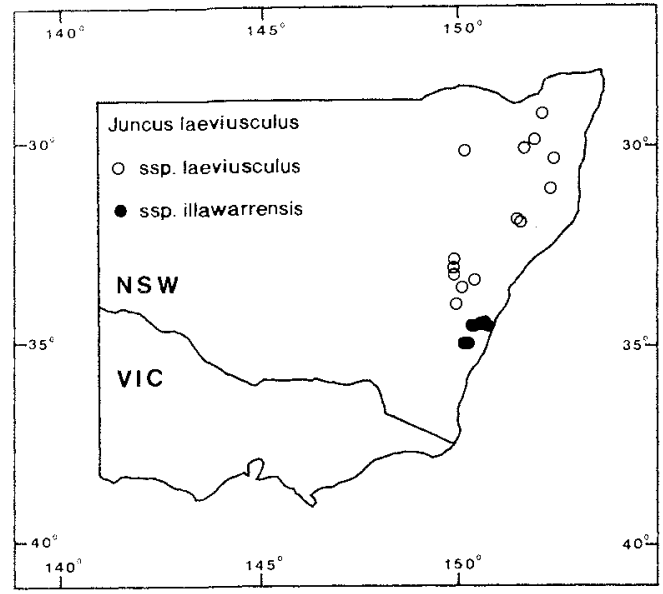

FIG. 2 - Distribution of J. laeviusculus: two subspecies.

\section{Holotype}

Dawsons Springs, Mt Kaputar National Park, $30^{\circ} 17^{\prime} \mathrm{S}$, $150^{\circ} 10^{\prime} \mathrm{E}$, alt. $1350 \mathrm{~m}, \mathrm{R}$. Coveny 8697 \& S. K. Roy, 17.xi.1976 (NSW). Isotype: CHR.

\section{Description}

Differs from $J$. alexandri in the smoothish, lightly striate culms with the epidermal cells over the sclerenchyma girders not or scarcely radially elongated, and the usually at least partly interrupted pith. The flowers are always small to medium (outer tepals $1.4-2.1 \mathrm{~mm}$ long) and the cataphylls are usually only moderately darkened towards the base.

The epithet is from the Latin, meaning "smoothish", the culms being less markedly striate than those of $J$. alexandri.

Two disjunct geographic races can be reconised as subspecies, distinguished as follows, on anatomical characters that call for sectioning and examination with the low power of a compound microscope:

1. "Cortical" air-spaces of the culms well developed; small sclerenchyma strands numerous. ............ subsp. laeviusculus

1 *. "Cortical" air-spaces absent or few; small sclerenchyma strands absent or few. .............. subsp. illawarrensis

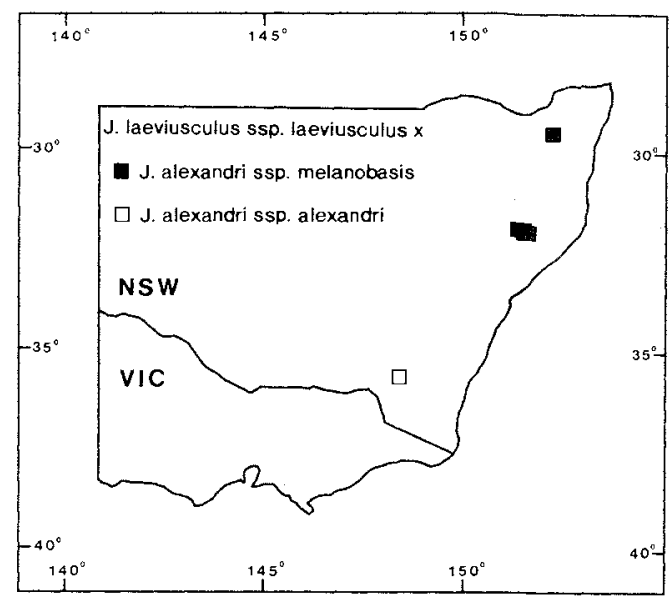

FIG. 3 - Distribution of hybrids or intergrades: $\square-\mathrm{J}$. alexandri $s s p$. alexandri $\times \mathrm{J}$. laeviusculus $s s p$. laeviusculus; - $-\mathrm{J}$. alexandri ssp. melanobasis $\times \mathrm{J}$. laeviusculus $s s p$. laeviusculus.

\section{J. laeviusculus subsp. laeviusculus}

\section{Distribution}

Northern and Central Tablelands of New South Wales, in moist cool forest country on soils of moderate or high fertility (fig. 2).

\section{Selected Specimens}

New South Wales: Northern Tablelands - Mt Sparrowby, 12 miles [20 km] c. ENE of Deepwater, E. Constable 7054, 21.viii.1966 (NSW); Mt Lindesay track near car park, Mt Kaputar National Park, 38 km ENE of Narrabri, R. Coveny 8960 \& S. Roy, 22.xi.1976 (NSW); Point Lookout, 45 miles [72 km] ENE of Armidale, G. Davis NSW 49590, 31.i.1941 (NSW); Hastings River Hwy crossing of the Forbes River, Mt Boss State Forest, J. Armstrong 200, 20.viii.1973 (NSW); $5 \mathrm{~km}$ north of Careys Peak, Barrington Tops, J. Pickard 1907, 30.xii.1972 (NSW); Gloucester Tops at turnoff to Careys Peak fire trail, L. Johnson 7609, S. Jacobs \& R. Coveny, 20.iii.1973 (NSW). Central Tablelands - Running Stream, Mt Vincent road, $0.5 \mathrm{~km}$ from Running Stream PO, L. Johnson 7583 \& S. Jacobs, 27.ii.1973 (NSW); Mt Horrible, 21 miles [34 km] northeast of Bathurst, C. Ingram 401, 5.iv. 1964 (NSW); Waterfall Gully, Mt Wilson, L. Johnson 7585 \& S. Jacobs, 27.ii.1973 (NSW); Mt Werong, R. Cambage 3170, 4.xii.1911 (NSW). 
This taxon is partly sympatric with $J$. alexandri subsp. melanobasis, and hybridism in this area is dealt with under the latter taxon. See also under $J$. alexandri subsp. alexandri for an apparent hybrid with that taxon, suggesting a more southward extension of $J$. laeviusculus than is represented by other specimens.

In marginal habitats, hybrids may also occur with $J$. continuus, a widespread species on more sandy soils. One small stand near Crawney Pass, south of Nundle, is probably a hybrid swarm with $J$. "sp. $\mathrm{D}_{2}$ ", which occurs in drier country nearby.

\section{J. laeviusculus subsp. illawarrensis L. Johnson, subsp. nov.}

A subspecie typica differt: lacunae aeruginosae culmorum nullae vel paucae; fasciculi sclerenchymatosi minores nulli vel pauci.

\section{Holotype}

Meryla Pass, about 5 miles [8 km] east of Bundanoon, $1200 \mathrm{ft}$ [c. $350 \mathrm{~m}$ ] alt., New South Wales [Central Coast], B.G. Briggs NSW 49101, 7.ii.1960 (NSW). Isotype: CANB.

\section{Description}

This subspecies is distinguished by the characters given in the key above. It sometimes has entirely continuous pith.

\section{Distribution}

On the eastern edges of the southern part of the Central Tablelands and the northern part of the Southern Tablelands of New South Wales and adjoining parts of the coast ranges, in moist forest country, usually on soils of moderate or high fertility (fig. 2).

\section{Specimens Examined}

New South Wales: Central Coast - Macquarie Falls, west of Albion Park, L. Johnson 7601, S. Jacobs \& R. Coveny, 12.iii.1973 (NSW); Carrington Falls, 17 miles $[27 \mathrm{~km}]$ c. east of Moss Vale, E. Constable 6266, 15.x.1965 (NSW); Jamberoo Pass, $5.6 \mathrm{~km} \mathrm{WSW}$ of Jamberoo, R. Coveny 7343, 17.xii.1975 (NSW, CHR, K). Central Tablelands - Burrawang Railway Station, at edge of Wingecarribee Swamp, L. Johnson 8014, 29.iii.1975 (NSW); $2 \mathrm{~km}$ southwest of Wildes Meadow, L. Johnson 8356, 15.x.1977 (NSW, CHR, K); Bundanoon to Glow Worm Glen, M. Tindale NSW 20864, 18.xi.1952 (NSW). Southern Tablelands Sassafras, L. Johnson 8034, 30.iii. 1975 (NSW); Endrick River Bridge, c. 7 miles [11 km] east of Nerriga on Nerriga-Nowra road, E. Constable NSW 46240, 27.x.1957 (NSW).
The epithet refers to the Illawarra district, on the western and southwestern edges of which the subspecies occurs.

\section{Juncus bassianus, sp. nov.}

Affinis J. alexandri, J. laeviusculi et J. astrepti, sed combinatione characterum sequentium distinguitur: cataphylla versus basin rubrobrunnea, cataphyllo longissimo 50-150 mm longo, 5-13 mm lato; culmi $0.5-1 \mathrm{~m}$ alti, (0.6)1.0-3.5 mm diametro, leviter striati, cellulis epidermalibus striarum haud elongatis, striis $30-50$, medulla continua; inflorescentia parva ( $14 \mathrm{~mm}$ longa vel rare usque ad $90 \mathrm{~mm}$ ), diffusa vel (praesertim in individuis depauperatis) aliquanto glomerata; tepala externa (1.9-)2.4-3.0 mm longa; capsula tepala excedens $2.4-2.6 \mathrm{~mm}$ longa, brunnea.

\section{Holotype}

Slopes of Mt Field East (c. 42 $40^{\prime} \mathrm{S}, 146^{\circ} 40^{\prime} \mathrm{E}$ ), Tasmania, J. Vickery NSW 60681, 17.i.1962 (NSW). Isotype: HO.

\section{Description}

With affinities to $J$. alexandri, $J$. laeviusculus and $J$. astreptus but distinguished by the following combination of characters: cataphylls reddish-brown towards the base, longest $50-150 \mathrm{~mm}$ long, $5-13 \mathrm{~mm}$ broad; culms $0.5-1 \mathrm{~m}$ tall (0.6-)1.0-3.5 mm diam., rather lightly striate, with the epidermal cells of the striations not radially elongated, striations $30-50$, pith continuous (or almost entirely so); inflorescence small (10-40 $\mathrm{mm}$ long or rarely up to $90 \mathrm{~mm}$ ), diffuse or (especially in depauperate individuals) somewhat clustered; outer tepals (1.9-)2.4-3.0 mm long; capsule exceeding tepals, $2.4-2.6 \mathrm{~mm}$ long, brown.

\section{Distribution}

Otway Peninsula, Victoria, and cooler moister parts of Tasmania, especially in the western half, in forest country especially in disturbed or open places (fig. 4).

\section{Selected Specimens}

Victoria: Otway Range: Stevenson Falls, Otway Forest, G. Earl 9, 9.ii.1984 (MEL); Yuulong to Crowes, Otway Peninsula, L. Johnson NSW 104635, 30.i. 1965 (NSW). Tasmania: North West - - Hellyer Gorge, G. \& C. Davis NSW 122201, 4.i.1937 (NSW). North East - Lilydale Falls, B. Robinson, 6.i.1982 (HO). West Coast Zeehan to Renison Bell, L. Johnson NSW 74396 , 6.i.1965 (NSW); Warners Landing road at Kelly Basin turnoff, K. Hill 1493, L. Johnson \& D. Blaxell, 23.ii.1986 (NSW, HO). Central Highlands - near Lake Little, Cradle Mountain, A. Buchanan 895, 31.i.1982 (HO); 
near Shadow Lake, west of Lake St Clair, B. Briggs 4716, iii.1973 (NSW); Lake St Clair, southern part, Cynthia Bay, Hj. Eichler 16690, 17.i. 1960 (AD, NSW); $12 \mathrm{~km}$ west of Lake St Clair, N. Laird, 13.iii.1976 (HO, NSW); King William Saddle, M. Phillips, 24.i.1962 (NSW, HO). Midlands - Mersey River (at Liena), A. Moscal 2370, 13.v.1983 (HO). South West Florentine Valley, about $10 \mathrm{~km}$ from Maydena, R. Melville 2349, J. Willis \& W. Curtis, 13.xii.1952 (K, MEL, NSW); Styx Valley, $14 \mathrm{~km}$ southeast of Strathgordon road on Styx road, at "Big Tree" site, S. Forbes 1297, 25.i.1983 (MEL, NSW); road to Hastings Caves, T. \& J. Whaite 2217, 19.i. 1961 (NSW, HO); D'Entrecasteaux at crossing of South Cape road, A. Orchard 5311, 26.i.1981 (HO).

There appears to be no contact between the occurrence of $J$. bassianus in the Otways and that of $J$. alexandri subsp. alexandri northeast and east of Melbourne. The distinctions between $J$. bassianus and J. astreptus and the apparently extensive hybridisation between them in Tasmania are discussed under the latter species. One collection appears to represent $J$. bassianus $\times$ $J$. gregiflorus L. Johnson; this is: Hartz Mountains, near hut at top of road, $43^{\circ} 13^{\prime} \mathrm{S}, 146^{\circ} 46^{\prime} \mathrm{E}, \mathrm{K}$. Hill 1553 , L. Johnson \& D. Blaxell, 28.ii.1986 (NSW).

We did not collect $J$. gregiflorus at this site, but in the field took this specimen to belong to that species. $J$. bassianus has been collected previously at the site. $J$. gregiflorus, though apparently rare in Tasmania, has been collected growing with J. bassianus in the West Coast Region, on the Warners Landing road at Kelly Basin turnoff, $42^{\circ} 19^{\prime} \mathrm{S}, 145^{\circ} 37^{\prime} \mathrm{E}$ (K. Hill 1492, L. Johnson \& D. Blaxell, 23.ii.1986 - NSW, HO), and also (but with other Juncus spp.) at $1.2 \mathrm{~km}$ west of Franklin River on Hobart-Queenstown road, $42^{\circ} 13^{\prime} \mathrm{S}$, $146^{\circ} 00^{\prime} \mathrm{E}$ (K. Hill 1497, L. Johnson \& D. Blaxell, 25.ii.1986 - NSW, HO). J. gregiflorus can be distinguished from J. bassianus and J. astreptus by the slender, soft stems with very open interrupted pith with large lacunae, and (at least in eastern Australia, including Tasmania) smaller flowers, usually in several clusters. It doubtless occurs elsewhere in cool moist parts of Tasmania, but a number of supposed collections have turned out to be J. astreptus or J. bassianus.

$J$. bassianus has at times been confused with $J$. australis Hook. f. which differs in the hard stems with interrupted pith, the silvery inner surface of the cataphylls and, most definitely, in the deeply sunken stomates.

The epithet bassianus is given on account of the occurrence of the species on both sides of Bass Strait, explored by Surgeon George Bass in 1797-99.

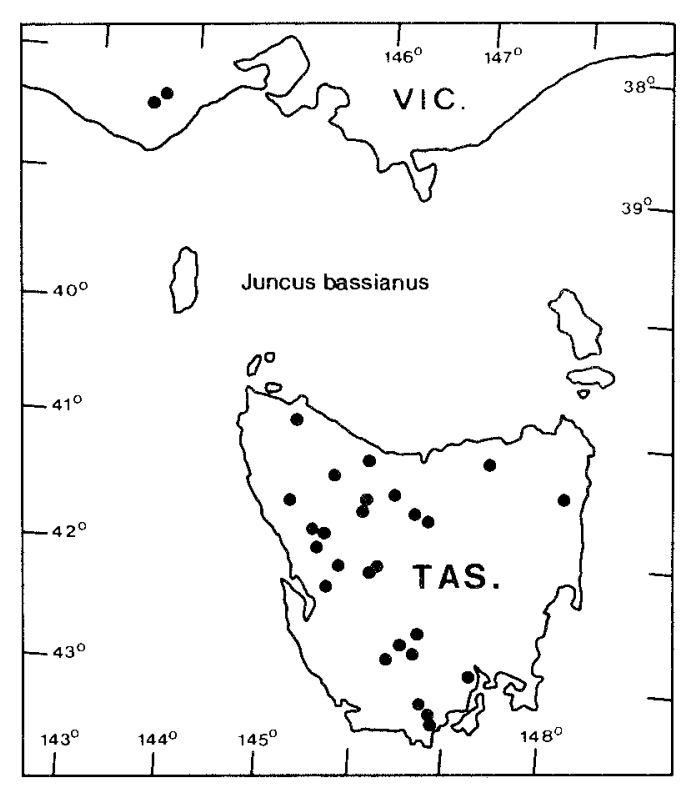

FIG. 4-Distribution of J. bassianus.

\section{Juncus astreptus L. Johnson, sp. nov.}

Affinis J. alexandri, J. laeviusculi et J. bassiani sed combinatione characterum sequentium distinguitur: cataphylla versus basin castanea vel brunnea, nec (vel vix) rubescentes nec atra, cataphyllo longissimo 45 $120(-150) \mathrm{mm}$ longo, $0.7-1.3 \mathrm{~mm}$ lato; culmi $0.6-1 \mathrm{~m}$ alti, $15-40 \mathrm{~mm}$ diametro, definite striata sed cellulis epidermalibus striarum non vel vix radialiter elongatis, striis 30-50, medulla omnino vel partim interrupta (rare continua in individuis depauperatis); inflorescentia arcte glomerata (aliquando pluriglomerata), (7-)10-30 mm longa; tepala externa $1.8-2.5 \mathrm{~mm}$ longa; capsula tepala subaequans, circa 2.0-2.4 mm longa, brunnea.

\section{Holotype}

Tasmania: Castle Forbes Bay, $43^{\circ} 08^{\prime} \mathrm{S}, 146^{\circ} 58^{\prime} \mathrm{E}$, W.M Curtis \& M. Allen 3, 22.v.1978 (NSW). Isotype: HO.

\section{Description}

With affinities to $J$. alexandri, J. laeviusculus and $J$. bassianus but distinguished by the following combination of characters: cataphylls light or dark brown but not markedly reddish towards the base, longest $45-120(-150) \mathrm{mm}$ long, $0.7-1.3 \mathrm{~mm}$ broad; culms $0.6-1 \mathrm{~m}$ tall, $15-40 \mathrm{~mm}$ diam., rather strongly striate but with the epidermal cells of the striations not or scarcely radially elongated, striations $30-50$, pith wholly or partly interrupted (rarely continuous in 


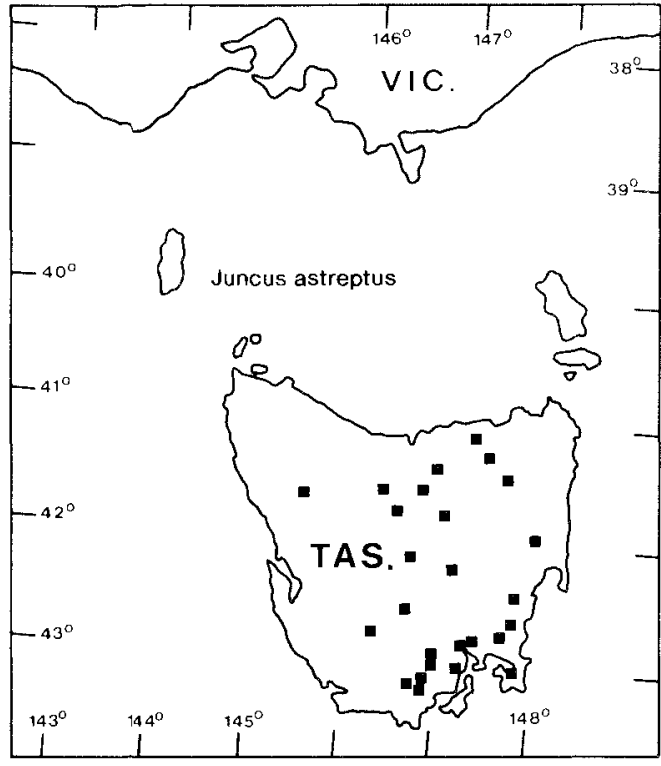

FIG. 5-Distribution of $\mathbf{J}$. astreptus.

depauperate individuals); inflorescence strongly clustered (sometimes with several clusters), (7-)10$30 \mathrm{~mm}$ long, outer tepals $1.8-2.5 \mathrm{~mm}$ long; capsule about equal to the tepals, c. $2.0-2.4 \mathrm{~mm}$ long, brown (except when old).

\section{Distribution}

Widespread in Tasmania, but more common in the east and generally associated with less moist forests than J. bassianus (fig. 5).

\section{Selected Specimens}

Tasmania: North East - Whites Mill Road, Lilydale, A. Buchanan 330 (in part), 30.xi.1980 (NSW ex HO). West Coast - Rosebery, R. Mason 13221, 7.i.1977 (HO ex CHR). Central Highlands - Gun Lagoon Creek, Devils Gullet State Reserve, A. Moscal 1664 , 3.ii.1983 (HO); Interlaken road, c. $14 \mathrm{~km}$ from Bothwell, W. Curtis, 18.ii.1976 (HO, NSW). Midlands - 1 mile [c. $1.5 \mathrm{~km}$ ] west of Poatina, L. Johnson NSW 74412, 4.i. 1965 (NSW, HO). Ben Lomond $-5.8 \mathrm{~km}$ from A3 highway on Mt Barrow Road, K. Hill 1589, L. Johnson \& D. Blaxell, 2.iii.1986 (NSW). East Coast - $34 \mathrm{~km}$ north of highway near Little Swanport along $M$ forest road, K. Hill 1566, L. Johnson \& D. Blaxell, 1.iii.1986 (NSW); Sheepdip Creek, A. Moscal 8108, 28.v.1985 (HO, VALD); eastern slopes of Blue Tier Range, c. $10 \mathrm{~km}$ WNW of Triabunna, M. Corrick 5832, 5.ii.1977

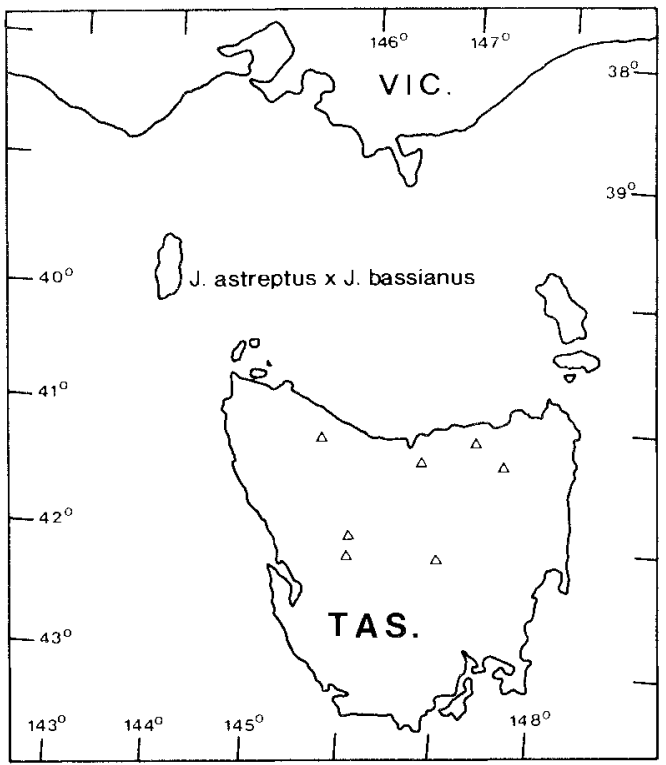

FIG. 6 - Distribution of hybrids or intergrades: $\mathrm{J}$. astreptus $\times \mathrm{J}$. bassianus.

(MEL); Nugent, R. Melville 2507, J. Willis \& H. Barber, 18.xii.1952 (K, MEL, NSW); west of Copping, L. Johnson NSW 10402, 15.i.1949 (NSW, HO); Taranna State Forest, Tasman Peninsula, R. Melville 2475, J. Willis \& H. Barber, 17.xii.1952 (K, MEL, NSW). South West - Kermandie, paddock of K. Geeves, Franklin, W. Curtis, 21.viii.1978 (HO).

The epithet is from the Greek a "not", and streptos "pliant, easily bent", in reference to the very rigid culms.

$J$. astreptus and $J$. bassianus represent different endpoints in morphological characters, and tend to occupy somewhat different habitats though they are partly sympatric. Nevertheless, many specimens show intermediacy and apparently represent considerable hybridisation and perhaps, in places, intergrading of whole populations. I suspect that this occurred to some extent before European settlement but has been greatly increased by the effects of land-clearing and roadbuilding, which have created extensive new habitats open to colonisation by Juncus species of this group. These hybrids or intergrades are mapped in figure 6 .

Selected Specimens ( $J$. astreptus $\times J$. bassianus, or derivatives):

Tasmania: Central Highlands - St Valentines Peak, near Guildford Junction-Hampshire Road, M. Phillips NSW 60769, 26.i.1962 (NSW, HO); 1 km east of Lake 
Solitude, west of Lake St Clair, B. Briggs 4715, iil. 1973 (NSW); Interlaken road, 9.7 miles [16 km] from Bothwell, D. Morris \& W. Curtis, 9.iv.1976(NSW). Ben Lomond - northem slope of Mt Barrow, L. Johnson NSW 74411, 4.i. 1965 (NSW); Ben Lomond National Park, M. Noble 28331, 10.ii. 1979 (HO).

\section{Hybridisation}

$J$. astreptus also appears to hybridise extensively with $J$. procerus E. Mey., a widespread species in Tasmania which also occurs, though often less commonly than in Tasmania, in wet parts of South Australia, Victoria, New South Wales, New Zealand (limited occurrence) and Chile. Again, the occurrence of these hybrid plants and populations has doubtless been much promoted by the effects of European settlement. They are mapped in figure 7 . It will be noted that this includes occurrences on the Bass Strait islands, where J. procerus is known but whence I have no specimens of "pure" J. astreptus; this may simply be a reflection of under-collecting.

Selected Specimens $(J$, astreptus $\times J$, procerus, or derivatives):

Tasmania: Furneaux - Lackrana (Max Hayden's property), Flinders Island, D. Morris, 9.xii.1975 (HO). West Coast - $24 \mathrm{~km}$ from Strahan on road to Queenstown, A. Orchard 5383, 8.ii.1981 (HO, NSW). Central Highlands - Arthur Lakes, at the outlet, Hj. Eichler 16946, 6.ii. 1960 (NSW); 7 km west of Lake Echo Dam on Bronte road, K. Wilson 6300, 15.ii.1986 (NSW, HO). Ben Lomond - Ben Lomond north slope, M. Noble 28781, 10.v.1979 (HO). East Coast - Fern Tree to Kingston, L. Johnson NSW 74399, 3.i.1965 (NSW). South East - Castle Forbes Bay, W. Curtis \& M. Allen, 22.v.1978 (HO, NSW); Huon River, marsh near Swamp Road (north of Franklin, opposite Egg Islands), N. Laird 14, 21.iii.1976 (NSW); Huon River, marsh near Franklin, N. Laird 28, 21.iii.1976 (HO).

\section{DWARF SPECIES OF SECTION SEPTATI}

Two Tasmanian and one mainland species have been confused with $J$. sandwithii Lourteig, a species of section Septati, of variable size but often dwarf and mat-forming. $J$. sandwithii was earlier confused with $J$. pusillus Buchenau, which is in fact confined to New Zealand. $J$. sandwithii was at first considered to be a Tasmanian endemic but is now known to be quite common on the Australian mainland at high altitudes from the Grampians in western Victoria through the eastern highlands of Victoria and the Tablelands of New South Wales as far north as Bald Rock National Park on the Queensland border. Hence it may be expected in Queensland. Moreover, I have seen one

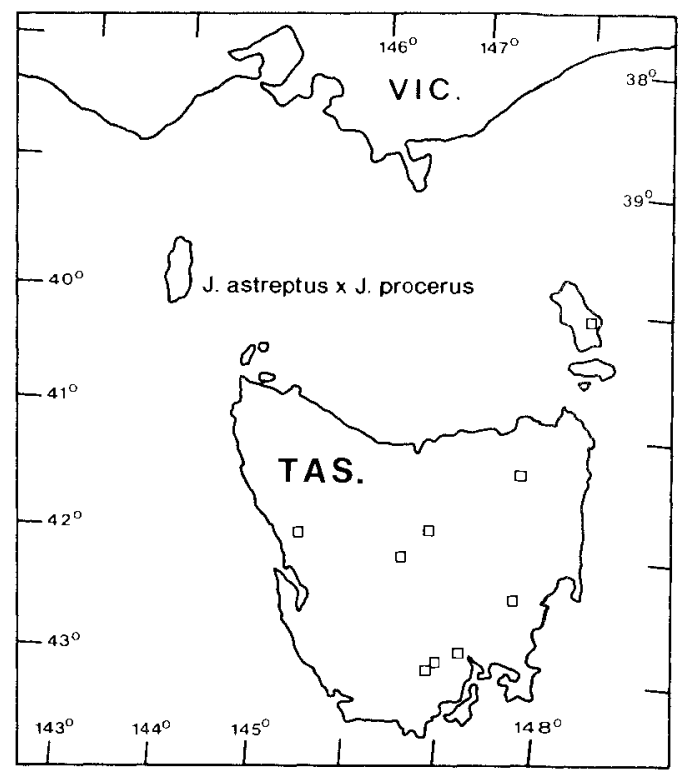

FIG. 7 -Distribution of hybrids or intergrades: J. astreptus $\times$ J. procerus.

collection of this species from Papua New Guinea: southeast end Isuani grassland southeast slopes to $\mathrm{Mt}$ Victoria, $8^{\circ} 55^{\prime} \mathrm{S}, 147^{\circ} 35^{\prime} \mathrm{E}$, alt. $2700 \mathrm{~m}$, J.R. Croft LAE 61840, 16.vii.1974 (NSW ex LAE, distributed under the misidentification " $J$. prismatocarpus" also to A, ATH, BISH, BRI, CANB, EDIN, K, L, MUN, US).

The species described below are quite sharply distinguished but superficially similar. $J$. curtisiae and $J$. thompsonianus are clearly vicarious sister species but $J$. ratkowskyanus is probably less closely related. $J$. curtisiae and J. ratkowskyanus are sympatric but may have subtle habitat differences of which I am not aware. All three of the new species are partly sympatric with J. sandwithii.

\section{Juncus ratkowskyanus L. Johnson, sp. nov.}

Affinis $J$. sandwithii Lourteig, ab hoc habitu humiliore, staminibus 3, tepalis exterioribus brevioribus quam eis interioribus, capsula abrupte acuminata et atrobrunnea, seminibus longioribus differt.

\section{Holotype}

Lake Seal, Mount Field National Park, Tasmania [42 $40^{\prime}$ S, 146 35'E], R. Carolin 1594, 27.i. 1960 (NSW). Isotypes: CANB, MEL, HO, SYD. 


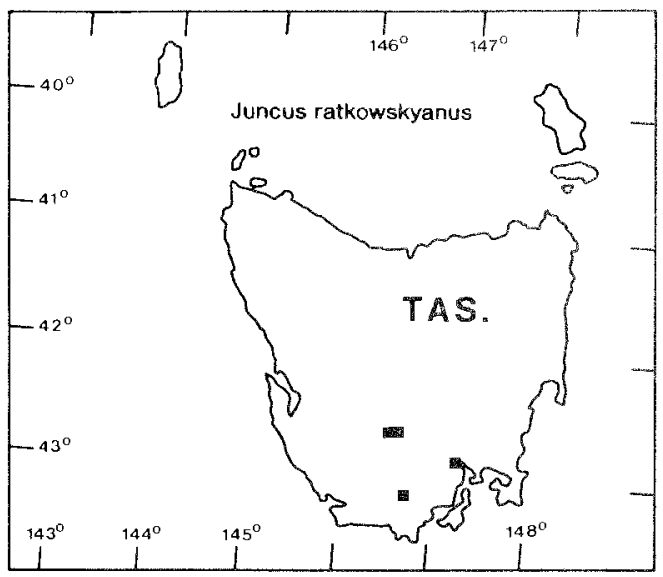

FIG. 8-Distribution of J. ratkowskyanus.

\section{Description}

Mat-forming perennial; rhizomes slender but older ones wiry, with long internodes, spreading with leafy ascending branches or ends. Ultimate culms $15 \mathrm{~mm}$ tall, c. $5 \mathrm{~mm}$ diam., terete, erect. Leaves unitubulose, terete, c. $0.5 \mathrm{~mm}$ diam., to $20 \mathrm{~mm}$ long, equal to or somewhat longer than inflorescence; auricles obtuse, c. $0.5 \mathrm{~mm}$ long; sheaths with 1-2 nerves on each side. Subtending bract equal to or somewhat longer than inflorescence; base somewhat broadened, \pm cellular-reticulate. Inflorescence of one head, rarely a second head present; heads 1-3-flowered. Outer tepals $2.3-3.0 \mathrm{~mm}$ long, inner slightly longer, all narrowlanceolate, acute, green or stramineous with hyaline margins, occasionally red-tinged, outer tepals shorter than inner tepals. Stamens 3; anthers (0.5-)0.7-1.0 mm long, c. one-third-one-half length of filaments. Capsule ovoid, rather abruptly acuminate, becoming dark redbrown, longer than or equalling tepals. Seeds ovoid, minutely apiculate, c. $1.0 \mathrm{~mm}$ long.

\section{Distribution}

Tasmania (southern, so far as known) at high altitudes in boggy places (fig. 8).

\section{Selected Specimens}

Tasmania: South West - Mt Field National Park, A.V. Ratkowsky, 20.xi.1973 (NSW); Mt Wellington, J.H. Hemsley 6710, 6.i. 1972 (NSW); southern end of Thark Ridge, Mt Wellington, D.A.\& A.V. Ratkowsky, 2.ii.1975 (NSW, CHR); Dead Island Bogs, Mt Wellington, A.V. Ratkowsky, 5.i.1975 (NSW, K); Mt Wellington, D.A. \& A.V. Ratkowsky, 31.xii. 1974 (NSW); Hartz Mountain National Park, D.A. \& A.V. Ratkowsky, 22.ii.1975 (NSW, HO).

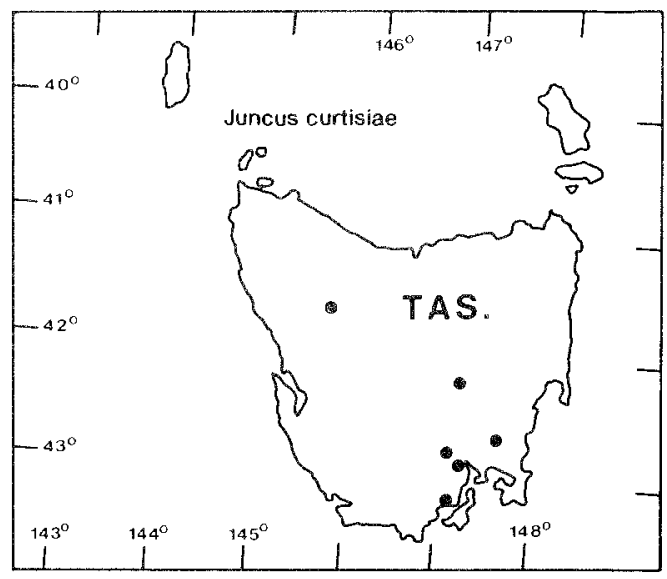

FIG. 9 -Distribution of J. curtisiae.

The epithet commemorates Dr David A. Ratkowsky and Mrs Ann V. Ratkowsky of Hobart, assiduous collectors and observers who first pointed out the distinctness of the species.

\section{Juncus curtisiae L. Johnson, sp. nov.}

Aff. J. sandwithii Lourteig, ab hoc habitu humiliore, tepalis exterioribus brevioribus quam eis interioribus, tepalis rubrobrunneis, antheris longioribus, capsula abrupte acuminata prominenter rostrata et rubrobrunnea differt.

\section{Holotype}

Table Mountain, alt. $\left.2500 \mathrm{ft}[750 \mathrm{~m}], 42^{\circ} 14^{\prime} \mathrm{S}, 147^{\circ} 08^{\prime} \mathrm{E}\right]$, Tasmania, D.A. \& A.V. Ratkowsky JS 101, 15.i.1975 (NSW). Isotypes: CANB, HO, MEL.

\section{Description}

Mat-forming perennial; rhizomes slender and with distant nodes, spreading with leafy ascending branches or ends. Ultimate culms $10-50 \mathrm{~mm}$ tall, c. $0.5 \mathrm{~mm}$ diam., terete erect. Leaves mostly caespitose, unitubulose, terete, c. $0.5 \mathrm{~mm}$ diam., to $5 \mathrm{~cm}$ long, equalling or somewhat exceeding inflorescence; auricles obtuse, c. $0.3 \mathrm{~mm}$ long; sheaths 3-4-nerved on each side. Subtending bract equalling or exceeding inflorescence; base broad, scarious. Inflorescence of one head, rarely a second head present; heads $1-4$ flowered. Outer tepals 2.0-2.5 mm long, inner slightly longer, all lanceolate, acute to obtuse, reddish with broad hyaline margins, longer. Stamens 6; anthers $0.7-1.0(-1.3) \mathrm{mm}$ long, c. half to two-thirds length of filaments. Capsule ellipsoid, triquetrous in distal portion; rather abruptly 
acuminate with a prominent beak, dark golden brown to red-brown, slightly exceeding tepals. Seeds ovoid, minutely apiculate, c. $0.5 \mathrm{~mm}$ long.

\section{Distribution}

Tasmania, in boggy places from low to high altitudes (fig. 9).

\section{Selected Specimens}

Tasmania: West Coast - Ocean Beach, Strahan, L.A.S. Johnson NSW 10419, 20.i.1949 (NSW, HO). Central Highlands - top of ridge west of Lake Dove, $4300 \mathrm{ft}$ [1240 m] elevation, just north of Cradle Mountain, P. Raven 25993, 25.ii.1970 (NSW). East Coast Ringarooma Creek, near Runnymede, A.V. Ratkowsky, 10.xi.1974 (NSW); Fern Tree pipeline, $1500 \mathrm{ft}[450 \mathrm{~m}]$, A.V. Ratkowsky, 4.ii. 1975 (NSW); Randall Bay, Cygnet district, M. Tindale NSW 30188, 13.xii.1954 (NSW). South West - Mt Wellington, $3700 \mathrm{ft}$ [1125 m], D.A. \& A.V. Ratkowsky, 5.i.1975 (NSW, CHR, HO); fire road near Trestle Mountain, Mt Wellington, D.A. \& A.V. Ratkowsky, 12.i.1975 (NSW, HO, MEL).

The species is named in honour of Dr Winifred Mary Curtis, doyenne of Tasmanian taxonomists.

\section{Juncus thompsonianus L. Johnson, sp. nov.}

Affinis J. sandwithii Lourteig, ab hoc habitu humiliore, tepalis exterioribus brevioribus quam eis interioribus, capsula acuminata differt.

\section{Holotype}

Wragges Creek, Kosciusko National Park, NSW, $36^{\circ} 23^{\prime} \mathrm{S}, 148^{\circ} 28^{\prime} \mathrm{E}$, alt. $1600 \mathrm{~m}$, K.L. Wilson 2033 , 3.ii.1979 (NSW). Isotypes: CANB, HO, MEL.

\section{Description}

Mat-forming perennial, rhizomes slender with distant nodes, spreading with leafy ascending branches or ends. Ultimate culms c. $5-30 \mathrm{~mm}$ tall, c. $0.5 \mathrm{~mm}$ diam., terete, erect. Leaves mostly caespitose, unitubulose, terete, $0.5-1.0 \mathrm{~mm}$ diam., to $70 \mathrm{~mm}$ long, usually much exceeding inflorescence; auricles \pm acute, c. $0.5 \mathrm{~mm}$ long; sheaths 3-4-nerved on each side with rather broad scarious margins. Subtending bract longer than inflorescence, base broad, scarious. Inflorescence of one head, rarely with a second head; heads 1-3-flowered. Outer tepals $1.8-2.1 \mathrm{~mm}$ long; inner tepals longer than outer tepals; outer tepals ovate, inner narrow-lanceolate; usually obtuse, green or stramineous with wide hyaline margins, occasionally red-tinged. Stamens 6; anthers $0.5-0.8 \mathrm{~mm}$ long, about half length of filaments. Capsule ovoid, rather abruptly acuminate, pale golden brown,

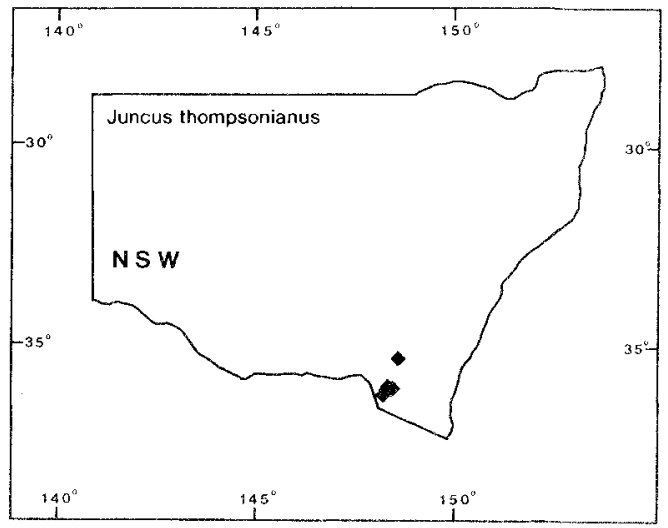

FIG. I0-Distribution of J. thompsonianus.

slightly exceeding tepals. Seeds ellipsoid, minutely apiculate, c. $0.5-0.7 \mathrm{~mm}$ long.

\section{Distribution}

Southern Tablelands of New South Wales, in the Snowy Mountains in moist and boggy situations. May be expected in the ACT and Victoria (fig. 10).

\section{Selected Specimens}

New South Wales: Southern Tablelands - Cave Creek, 18 miles $[30 \mathrm{~km}]$ NNE of Kiandra, A. Rodd \& R. Coveny 2675, 12.xii. 1969 (NSW, CANB, P); base of Mt Piper, near Smiggins-Guthega Road, Kosciusko National Park, J. Thompson 2438a, 23.i.1976 (NSW, CANB, MEL); Perisher Creek, Kosciusko National Park, J. Thompson 2699, 27.i.1977 (NSW); Blue Cow Creek, Kosciusko National Park, J. Thompson 853, 21.i.1971 (NSW); Lower Spencers Creek, J. Thompson 1690, 22.i.1973 (NSW, CHR, HO); Munyang River, at Whites River Hut, southern side of Schlink Pass, Kosciusko National Park, K. Wilson 6147, 14.ii.1985 (NSW); Big Boggy near Dead Horse Gap, $1620 \mathrm{~m}$, Kosciusko National Park, J. Thompson 1409, 12.1.1972 (NSW, MEL).

J. thompsonianus is a mainland vicariant of J. curtisiae, distinguished chiefly by the shorter flowers and non-reddish tepals. There are no intermediates.

The species is named in honour of Mrs Joy Thompson, who has observed and collected it in many localities in the Snowy Mountains, in the course of extensive studies in the region. 


\section{ACKNOWLEDGEMENTS}

I thank Dr Winifred Curtis as well as Dr David and Mrs Ann Ratkowsky for drawing my attention to new taxa in Tasmania. Of my colleagues at NSW, I particularly thark Karen Wilson for continued assistance in the study of Juncus, as well as Siegfried Krauss for preparing the distribution maps and other assistance with this paper, and Joy Thompson for critical collection. Dr Barbara Briggs has provided most helpful comments and facilities; others who have assisted in various ways include Dr Mary Tindale, Sharron Armitage, Pauline Shires and Leonie Stanberg. The National Herbarium of New South Wales contributed directly to the cost of publication of this paper.

\section{REFERENCE}

JACOBS, S.W.L. \& PICKARD, J., 1981: PLANTS OF NEW SOUTH WALES. Government Printer, Sydney: 1226.

(accepted 10 August 1990)

L.A.S. Johnson

Royal Botanic Gardens, Sydney, NSW, Australia 2000 